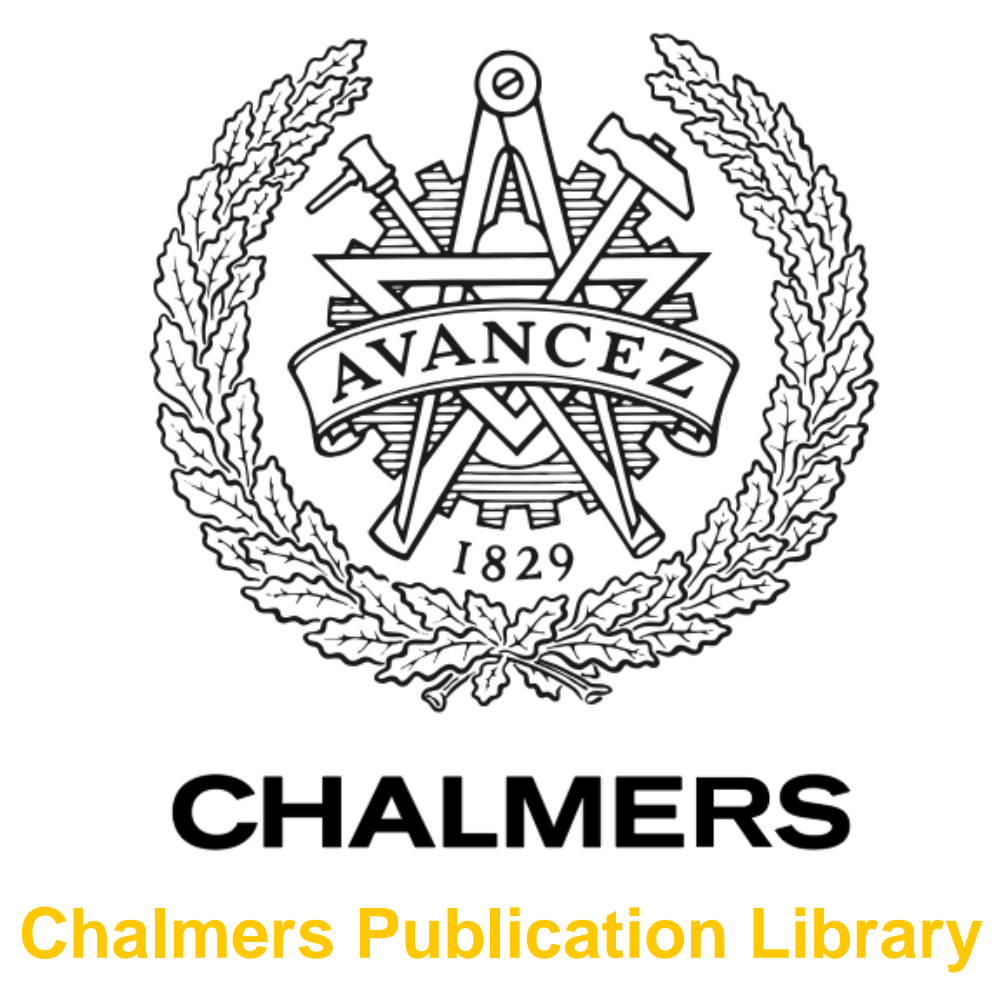

Exploring Quality Challenges and the Validity of Excellence Models

This document has been downloaded from Chalmers Publication Library $(\mathrm{CPL})$. It is the author's version of a work that was accepted for publication in:

International Journal of Operations \& Production Management (ISSN: 0144-3577)

Citation for the published paper:

Eriksson, H. ; Gremyr, I. ; Bergqvist, B. et al. (2016) "Exploring Quality Challenges and the Validity of Excellence Models". International Journal of Operations \& Production

Management

Downloaded from: http://publications.lib.chalmers.se/publication/227278

Notice: Changes introduced as a result of publishing processes such as copy-editing and formatting may not be reflected in this document. For a definitive version of this work, please refer to the published source. Please note that access to the published version might require a subscription. 


\section{Exploring Quality Challenges and the Validity of Excellence Models}

Purpose: The purpose of this study is to identify and explore important quality-related challenges facing organizations, and investigate how current excellence models incorporate these challenges.

Methodology: The article is based on a Delphi study of Swedish organizations. Forty-nine challenges were generated and ranked according to importance and the 10 top-ranked challenges were compared to the principles of four excellence models.

Findings: The excellence models still seem to be relevant since their content matches many of the identified challenges. The MBNQA and the SIQ models were found to have the most comprehensive coverage, while the ISO model had limited coverage.

Research Limitations/Implications: Three areas for further research were identified: (1) How quality management can evolve in different contexts that have varying needs in terms of adaptive and explorative capabilities; (2) the interfaces of QM and sustainability, and ways to understand how customers and stakeholders can be active contributors to improvements; and (3) the roles of the owners and board of directors regarding $\mathrm{QM}$, and how to organize and distribute responsibilities of the $\mathrm{QM}$ work.

Practical and Social Implications: There are three important challenges that future revisions of excellence models could address: (1) Making QM a strategic issue for company owners; (2) involving customers in the improvement activities; and (3) developing processes that are robust yet still easily adaptable.

Originality/Value: The Delphi study identified upcoming challenges in the QM area based on input from 188 quality professionals.

Keywords: Delphi study, quality management (QM), Excellence models, ISO 9000, EFQM model, MBNQA.

Article classification: Research paper 


\section{Introduction}

Quality management (QM) has been presented in many guises and with various definitions. Common tenets include improving processes and services systematically and continuously, using fact-based decision making, and instigating a quality culture, see Flynn et al. (1994), Kaye and Anderson (1999), and Sousa and Voss (2002). An organization uses QM in order to fulfill the implicit or explicit requirements and needs of its customers, its users, and its stakeholders. The common ground can be described by some general principles for QM. For example, Dean and Bowen (1994) argued that the key principles of QM are to focus on the customer, to make continuous improvements, and to engage in teamwork. One basic objective of QM has been to achieve positive effects on business results, as expressed by Shewhart (1931) and later empirically shown by Hendricks and Singhal (1997), Sila and Ebrahimpour (2002) and Eriksson and Hansson (2003).

There are now many examples of concepts that have evolved from QM, including Lean and Six Sigma (Byrne et al., 2007). The economic potential of QM has also created a market for consultants, who tend to adopt novel management concepts (Näslund, 2008) and, by so doing, lend credibility to such concepts (Miller and Hartwick, 2002). However, new management concepts often have common roots (Byrne et al., 2007). In addition to the different management concepts related to $Q M$, excellence models have also been developed to describe the traits of QM in successful organizations. The Malcolm Baldrige National Quality Award (MBNQA) (see NIST, 2014) was one of the first Western excellence models. Later the European Foundation for Quality Management's model (EFQM) (see EFQM, 2013) was introduced in Europe alongside several national models, such as the Swedish Institute for Quality's model (SIQ) (see SIQ, 2014). All of these models were designed to help rate the maturity of $Q M$ and business excellence in an organization. Another type of excellence model is that of the International Organization for Standardization (ISO), whose ISO 9001 standard is widely applied in industry today. ISO 9001 certifications, like the application of excellence models, have often been used as proxies for QM adoption (Wiengarten et al., 2013).

Several studies have investigated, often by means of surveys and analysis of fiscal data, the impact that an ISO 9001 adoption (see, for example, Benner and Veloso, 2008; Martínez-Costa et al., 2009; Chatzoglou et al., 2015; Cândido et al., 2016) or receipt of an excellence award (see, for example, Hendricks and Singhal, 1999; Eriksson and Hansson, 2003) has on the organizational and financial performance of an organization. However, Chatzoglou et al. (2015) concluded in their literature review that "no coherent results have been yet produced" regarding how an ISO implementation affects various measures of organizational and economic success. On the other hand, the same authors also found evidence in their study that an ISO 9000 implementation is associated with improved overall financial performance. Research into the successful implementation of excellence models, often manifested with receiving an excellence award, showed early effects on various business results, both in America (Hendricks and Singhal, 1997) and in Europe (Eriksson and Hansson, 2003). More recent research on excellence models has focused on how certain criteria or practices in the excellence models positively affect performance (Calvo-Mora et al., 2014; Sabella et al., 2014). In the EFQM, these criteria include the management of human resources, the strategic management of partnerships and resources, and process management 
(Calvo-Mora et al., 2014). In the MBNQA, they include people management, process management, and information and analysis (Sabella et al., 2014).

Despite the large amount of research into the organizational effects of excellence model implementations, less attention has been given to problematizing the validity of excellence models. Researchers have criticized the slow development and adoption of new relevant content of these excellence models (Williams et al., 2006; Asif et al., 2011). Williams et al. (2006) discussed why the excellence models might no longer be relevant or useful unless they are revised. Specifically, researchers have questioned the practical validity of models developed in the 1980s for the current business environment; for example, Asif et al. (2011) argued that sustainability issues are not enough represented in the excellence models. In one of few empirical studies on the validity of excellence models, Jayamaha et al. (2009) used scores from award applicants to conclude that more attention should be given to enhancing the precision of criteria and how they are measured in future model revisions.

The present article aims to highlight two issues. The first issue relates to the future challenges organizations face in the QM area. Sousa and Voss (2002) argued that one alternative for research on QM is to extend and add new content to face contemporary challenges and interest by practitioners; that is, "to re-package QM and make it more sellable after its initial hype and partly to [meet] the real needs of current businesses" (ibid: p. 94). However, they also argued that such a repackaging must be applied cautiously to avoid diluting the core of QM (Sousa and Voss, 2002). The second issue highlighted in the present article concerns the wide adoption of the business excellence models. The excellence models have been deployed by organizations since the late 1980s and are still applied by organizations around the world every day (Talwar, 2011). As the models are widely applied, it is essential to evaluate how existing excellence models conform to the challenges that contemporary organizations face in the QM area. In other words, it is essential to study whether the excellence models are still valid as a way to support QM in practice.

The purpose of this article is to identify and explore important quality-related challenges facing organizations and how current excellence models incorporate these challenges. The match between challenges and excellence models is studied in order to pin-point research and development needs regarding excellence models and QM. The purpose can be broken down into the following three research questions:

\section{What are the future quality-related organizational challenges?}

2. Do current excellence models address these challenges?

3. What are the implications for future research on business excellence and QM?

The article starts with a theoretical framework that focuses on QM and excellence models, which leads to two research propositions that are later contrasted with the empirically derived challenges. The study is based on a Delphi methodology, aimed at identifying the challenges that organizations in Sweden will face in the next 10 years. The excellence models are then evaluated against these challenges. Finally, the article ends with a discussion and conclusions. 


\section{Theoretical Framework}

The theoretical framework is based on two parts - QM and excellence models - as a basis for addressing the potential of excellence models to face upcoming QM challenges and still remain aligned with basic QM principles.

\section{Quality Management}

According to Lengnick-Hall (1996), the evolution of QM can be characterized by six phases: craftsmanship, inspection, statistical quality control, quality assurance, strategic quality management, and sustainable competitive quality. Initially, the quality of a product was linked to its craftsmanship, and later to an inspection of the final product. Shewhart $(1931,1939)$ introduced statistical quality control, which since Taylor (1911) had been directed toward management control and the post-production inspection of products. While ideas such as standardization, management by facts, waste reduction, and an emerging customer orientation can already be found in Taylor (1911), the introduction of statistical quality control made it possible to identify problems earlier in the production chain and to better control production processes during on-going production. Quality assurance, the phase following quality control, broadened the focus to include areas of management outside production (Garvin, 1988; Yong and Wilkinson, 2002). Quality assurance has been given different meanings (see, for example, Garvin, 1988), but in the present context it refers to the effort to standardize procedures to establish and use third-party certified QM systems. While standardization started at the turn of the twentieth century (Yong, and Wilkinson, 2002), the ISO 9000 standards, first published by the ISO in 1987, have had a major worldwide impact on organizations. In 2013, over 1.1 million organizations had third-party certification (Heras-Saizarbitoria and Boiral, 2013). The strategic quality management phase quickly spread during the 1980s and 1990s. In this phase, total quality management (TQM) evolved as a concept that can briefly be described as a system's approach to creating a customer-focused and process-focused organization in which processes are continually improved.

Following the TQM movement, the standardized approaches to QM have been criticized for not considering variations between application areas, such as product innovation processes versus production processes. Research on ambidexterity (O'Reilly and Tushman, 2008; Raish et al., 2009) suggests that the first capability an organization needs is related to the exploitation of existing capabilities, and the second is to be able to master the exploration of new opportunities. Benner and Tushman (2003) argued that process management, an important element in $\mathrm{QM}$, is well suited to a stable environment characterized by exploitation. In turbulent environments, however, these practices fail to support exploration (Benner and Tushman, 2003). The difficult balance between exploitation and exploration is also evident from the roles of quality professionals, which are often limited to ISO systems and certificates (Elg et al., 2011). Watkins (2006) argued that this specialization of the QM profession is overly defensive and needs to be widened to encompass overall business management. Stratton (1996) pointed out that while the quality professionals can occupy strategic roles, the responsibility for quality cannot rely solely on the quality professionals and must also fall upon managers in general. In addition, Alänge and Steiber (2009) argued that it is critical for the owners to also take responsibility for quality. 
The chronological evolution described by Lengnick-Hall (1996) ended almost two decades ago. Sousa and Voss (2002) argued that QM is a mature field, but that constant additions and developments carry "the danger of dissolving QM's identity as a field of study and threaten the soundness of the field's conceptual foundations." They further argued that one approach to QM research is to adhere to the foundations and core principles of QM while framing "the much needed research in these new areas as research conducted at the interface between core QM and other fields' (ibid.). Other fields, such as new contexts of application, inter-firm linkages, and networks of companies, point to a wide range of adjacent areas that are of interest to study from a QM perspective. Such a broadened study is particularly relevant since quality is not only in focus in the traditional manufacturing industry, but also in areas such as healthcare (Batalden and Davidoff, 2007), manufacturing firms undergoing servitization (Gremyr et al., 2010; Fundin et al., 2012), and organizations in areas characterized by value co-creation with customers (Normann and Ramirez, 1993; Witell et al., 2011). Challenges arise as the organizational environment changes due to new requirements, such as environmental considerations and the need to integrate sustainability considerations in QM (Angell and Klassen, 1999; Bergquist et al., 2012; Gremyr et al., 2014). The continued adoption and adaptation of the QM concept outside its original domain points to a need for continuous research on applicability of QM in new domains in the future (Genovich-Richards, 1997; Elg et al., 2011).

Proposition I: QM is continuously developing and adapting; therefore, future important quality-related organizational challenges will lie outside the current QM domain.

\section{Excellence Models}

Various excellence models have sought to describe practices of successful organizations. Historically, this started in Japan with the Deming Prize, which was established in 1952, primarily to recognize the work of successful organizations (Ghobadian and Woo, 1994). During the 1980s, when Western countries realized how successful many Japanese companies had become by focusing on quality and continuous improvements, similar models were developed in these countries.

However, the organizational value of applying excellence models is controversial. The main drawbacks are the resource-demanding activities involved and the detailed model criteria (Eriksson, 2003a; Eriksson and Garvare, 2005). A major advantage, on the other hand, is the improvement work initiated and thereby improved results (Eriksson, 2003b). The models are often regarded as guides to excellence and good practice for QM. This view is partly based on the effect that the application of excellence has on business results (Hendricks and Singhal, 1997; Eriksson and Hansson, 2003), but also on how these models are seen as the operationalization of QM (Sila and Ebrahimpour, 2003). It has been argued that the criteria of excellence models conform to the major principles of QM (Ghobadian and Woo, 1994; Hendricks and Singhal, 1999; Tan et al., 2003). The different core principles and values at the foundation of a selection of excellence models are presented in Table 1.

Insert Table 1 here 
Table 1 shows that there are many similarities between the excellence models. All excellence models include leadership, people, customer and/or improvement/innovation aspects. Management by facts, agility, and sustainability are other frequent principles, or values, in the excellence models. There are also differences across the excellence models, including an emphasis on different aspects of $Q M$, and varying numbers of core values and principles.

The excellence models have undergone large and small changes. The new standard of ISO 9001 will be launched in the fall of 2015. The only change with regard to QM principles in the recently published draft standards (ISO/DIS 9001) is that the "system approach" principle has been removed. Williams et al. (2006) suggested that the practical validity of excellence models should be questioned since the models were developed during the 1980s, and as contemporary organizations face new challenges. There has been criticism of the content and validity; specifically, whether the models are actually measuring what they intend to measure (Williams et al., 2006; Jayamaha et al., 2009; Asif et al., 2011). The counter-argument to this view is that the excellence models are regularly revised and updated (Karimi et al., 2014). Recent changes have led to aspects such as societal responsibility and financial status receiving more weight in the evaluation of results, at the expense of organizational processes and results related to customer satisfaction (Asif et al., 2011). Talwar (2011) stated that excellence models and the changes they undergo are due to the evolution of the external environment and that the models should reflect contemporary approaches to QM. This leads to the following proposition:

Proposition II: The current principles and values of the excellence models do not support organizations when they are faced with future quality-related challenges.

\section{Empirical study}

The study was led by a research team, including all the authors of this article, at the Swedish Quality Management Academy (SQMA), which is a network involving eight Swedish universities that conduct research and education on QM.

\section{The Delphi Methodology}

The empirical study was performed with the use of the Delphi methodology, an interactive approach that seeks to obtain a reliable consensus from a group of experts (Rescher, 1998). This method was first developed in the 1950s as a way of structuring group communication with feedback regarding individual contributions, assessing group judgments, providing opportunities for individuals to revise their views, and offering a degree of anonymity for the individual respondents (Linstone and Turoff, 1975). An underlying principle of the method is that "two heads are better than one" (Dalkey, 1969), which allows for a broad understanding of complex problems (MacCarthy and Atthirawong, 2003). Another underlying principle is that the method helps to remove the pressure on the respondents to respond in certain ways; for example, by group pressure, by the influence of status, or by rhetoric (Aichholzer, 2009). Okoli and Pawlowski (2004) provided guidelines regarding how to conduct Delphi studies, concluding that the use of the method is particularly valuable in the early stages of research by identifying research topics and defining research questions. In the Delphi method, participating experts normally respond to a questionnaire in two or three rounds. After each round, an anonymous summary is presented, consisting 
of the experts' responses from the previous round, as well as qualitative motives for the responses. In each new round, the participants are encouraged to review their previous entries in light of the anonymous summary. The design used in the present study could be categorized as an e-Delphi design (Keeney, 2009), with experts approached via email and online web surveys.

\section{The Pilot Delphi Study}

A pilot study was performed prior to the actual Delphi study. The pilot study began with a group of 12 researchers from the SQMA network brainstorming about potentially critical QM challenges for the next 10 years. All of the researchers had extensive experience in practice and research in the field of $Q M$, so the original challenges were not theory-driven explicitly. However, because the researchers had similar backgrounds and experience in the field of QM, it can be argued that the challenges implicitly sprung from theory and current practice of $\mathrm{QM}$. The researchers were instructed to formulate what they considered to be the most important QM-related challenges organizations will be facing in ten years' time. The challenges were written on Post-it notes that the researchers grouped according to themes using the affinity technique (Kawakita, 1981).

Two of the researchers reviewed and reformulated the challenges after the seminar in order to avoid challenges that had similar content and to standardize the language and scope. This resulted in a total of 65 challenges, which, together with accompanying instructions, were then sent to all 17 researchers who were active within the SQMA network at the time, including the authors of the present article. The aims for this stage of the process were: (1) to decrease the number of challenges required to make the process viable; (2) to see whether any challenges needed to be re-formulated; and (3) to test the Delphi methodology. The questionnaire was sent electronically via a survey system on three different occasions; 16 out of the 17 researchers participated in the full three-step pilot study. Respondents were asked to select the 10 most important challenges from the list of challenges and to provide reasons for their choices. Respondents could also add to the list of challenges and provide reasons for doing so. New challenges and motives were visible to the respondents in rounds two and three. The researchers also provided feedback about the questionnaire, the instructions, and the methodology at each round. Challenges that were not chosen by any respondent during any of the first two rounds were excluded from round three. In the third and final round, no new challenges could be added and the respondents were asked to choose 10 challenges (out of 49) and to rank them based on perceived importance. During the pilot study, many researchers suggested that it was necessary to direct the respondents to answer the questionnaire with a QM focus so that the results would not be side-tracked to areas such as government policies and financial markets. In response to this concern, the authors designed a cover letter introducing the survey and explaining the focus of the challenge. After duplicates were removed, 38 challenges were chosen as important by at least one of the pilot study respondents. These challenges were included in the Delphi study. An overview of the pilot study is illustrated in Figure 1.

Insert Figure 1 here 


\section{The Delphi study}

A key step in the Delphi method (Häder and Häder, 2000) was the selection of individuals to be included as experts. The experts or respondents should have an appropriate knowledge of the subject matter and be motivated to take part in all rounds of the study (Aichholzer, 2009). Three hundred and fifty-seven qualified quality professionals were selected as respondents, having been identified via the SQMA network as having extensive experiences of QM and an overview of their industry. The study aimed to identify future QM challenges across industries, and participants were selected from both public and private organizations. Further, respondents held a variety of positions, including general managers, development managers, quality managers, chief executive officers, product development managers, unit heads, researchers, consultants and IT specialists. Despite the large number of different roles represented, all had worked, were working, or had other relevant experience with QM. As with the pilot study, the regular Delphi study was carried out over three rounds. All respondents were contacted at each step, regardless of whether they had participated in the previous step. At each step, the respondents were given the following instruction: "Based on your collective experience of organizations in Sweden, select which 10 challenges in the list you think will be of most importance over a ten-year period, and justify your selection." The results of the study built on the 188 individuals who responded in one, two, or all three rounds of the web-based questionnaire. The respondents represented a wide range of organizations in both the private sector (59 percent, $n=111$ ) and the public sectors ( 41 percent, $n=77$ ) in Sweden. Of the 111 respondents in the private sector, 53 categorized themselves as goods manufacturers and the other 58 categorized themselves as service providers; 59 reported that they operated primarily in Sweden, and 52 primarily operated internationally.

\section{Round 1}

In the first stage, the participants were asked to select the 10 of the 38 challenges they thought would be most important in ten years' time. The challenges were presented in random order and the respondents were asked to justify their choices. The respondents also had the opportunity to suggest and provide motives for additional challenges. The response rate was 39 percent $(n=142)$. The respondents suggested 173 new challenges in round 1. Two of the authors analyzed these challenges and the justifications. In order for a new challenge to be added at round 2, it had to fulfill the following criteria: the challenge should not be covered by the challenges already included, it should be proposed by at least three respondents, and it should have the potential to be reformulated into a clearly-defined challenge. This resulted in nine additional challenges being added to the original 38 .

\section{Round 2}

To allow the respondents to review and be influenced by the motives given by other respondents, all motives for choosing a particular challenge in round 1 were displayed alongside the challenge prior to the second round. In this round, the respondents were asked to select 10 out of the 47 randomly listed challenges. As in round 1, there was an opportunity to suggest additional challenges and provide reasons for doing so. One hundred and forty additional challenges were suggested and these were analyzed by the same two authors as in round 1 . The criteria for including a new challenge after round 2 were the same as in round 1. Two new challenges were added. The response rate in round 2 was 34 percent $(n=$ 122). 


\section{Round 3}

In round 3, all 357 respondents were again invited to evaluate the 49 challenges. The response rate in this round was 35 percent $(n=126)$. All motives from rounds 1 and 2 were displayed alongside the specific challenge, which enabled respondents to take part and be influenced by the reasoning of other respondents. None of the previous motives were omitted. During this final round, the respondents were also asked to rank the 10 selected challenges based on their perceived importance for their organization in the next 10 years. The rankings ranged from 1 (most important) to 10 (least important).

\section{Data Analysis}

The initial analysis sought to understand which of the 49 challenges were considered most vital. As the final round included ranking from 1 to 10 , averaging the ranks would downplay the challenges that only a few respondents considered important, as opposed to those that many saw as slightly important. The former could be crucial to certain industries or sectors, yet insignificant for others. Therefore, the reciprocal of the score was used, which meant that the highest ranked challenge was given the weight 1 , the second most important was given a weight of $1 / 2$, the third most important was given the weight of $1 / 3$, and so on; and then all weights for each challenge were summed into a 'sum of scores' index. Stepwise regression was used to control for the possibility that background variables could affect the respondents' views about which of the top 10 challenges were most important in round 3 . These background variables included professionals working for: (1) organizations with international operations $(n=34)$ and organizations with operations only in Sweden ( $n=92) ;(2)$ private organizations $(n=73)$ and public organizations ( $n=53)$; and (3) manufacturing organizations $(n=31)$ and service providers $(n=95)$.

Secondly, we aimed to explore whether current excellence models sufficiently address the identified challenges. Correspondence between challenges and selected excellence models (MBNQA, SIQ, EFQM, and the ISO 9000 series) was analyzed via inter-coding. Seven of the authors coded each of the 49 challenges and all four models as follows: challenges and model principles that were considered to be strongly associated were marked with the number of the principle. Weak associations were indicated by putting the number within brackets. If no associations were found, nothing was marked for that specific challenge. This analysis was used to calculate how well the models covered the challenges. Complete coverage (100 percent) implies that all researchers found strong associations between the challenge and the QM model. No coverage (0 percent) implies that none of researchers indicated any association. If all researchers categorized a challenge with a weak association, 50 percent coverage was allocated. Coverages for the top 10 challenges are presented.

To assess inter-coding reliability, the coding was operationalized into three scenarios: (1) no association identified by any of the seven authors; (2) one or more weak associations identified, but no strong ones; and (3) at least one strong association identified. The percentage of agreement was chosen as the primary index, with a minimum acceptable level of reliability selected as 70 percent (Lombard et al., 2002), a liberal level motivated by the large number of coders. The more conservative Krippendorff's alpha index (Krippendorff, 1980) was used as a complement. All 1372 relations were examined (that is, 49 challenges multiplied by four models and seven coders). The mean value of percentage agreement shared was an acceptable 71 percent. The Krippendorff's alpha index was 44 percent, which indicated that the results should be treated with caution. 


\section{Empirical findings}

Results from the study are presented in the two sections below. The quality-related challenges are discussed and the top 10 challenges are compared with the excellence models.

\section{Quality related challenges}

The quality-related challenges that were anticipated by the respondents are displayed in Table 2, along with the total scores the respective challenges received using the weighting system explained above. The top three challenges stand out clearly when looking at the sum of scores.

No significant differences were found concerning controlling for the respondents' organization type (whether large or small, private or public, or manufacturing or service) regarding the ranking of the top 10 challenges. The respondents working in international organizations answered differently from those in Swedish organizations, and a difference was found for challenges ranked 5,6 , and 7 . The international respondents ranked the challenge ranked 5 - "To lead and implement change" $(p=0.013)$ - and the challenge ranked 6 - "To develop processes that are robust, while still easily adaptable" $(p=0.003)$ - as the most important. The respondents representing Swedish organizations, on the other hand, considered the challenge ranked $4-$ "To develop an improvement culture within the organization" $(p=0.039)$ as more important.

Insert Table 2 here

\section{The Challenges and the Excellence Models}

Table 3 shows how the excellence models cover the most important challenges. The challenge ranked as the third most important - "Making quality management a strategic issue for company owners" - is not covered well by any of the examined models. EFQM and ISO 9000 also fail to address the most highly ranked challenge, which was "To transfer the ownership of quality from the quality profession to management." ISO 9000 fails to cover the second most highly ranked challenge, which was "To make the organization agile and adaptable to rapid changes within the business environment." In the theme of customer collaboration, the challenge "To involve customers in the improvement activities" stands out with low coverage in the excellence models. In the theme of change, improvement and adaptability, the challenge "To develop processes that are robust, while still easily adaptable" has low coverage in the models (both below 0.5). From the four models, MBNQA and the SIQ models have the best general coverage, and the ISO 9000 model covers the challenges the least.

Insert Table 3 here

\section{Discussion}

This article set out to identify and explore important quality-related challenges facing organizations and how current excellence models incorporate these challenges. Two propositions affecting the development 
of QM and the excellence models were derived from previous research on excellence models in specific and $\mathrm{QM}$ in general. These propositions are elaborated upon below in light of the empirical findings. This section ends with discussions on possible research limitations.

\section{Proposition I: QM is continuously developing and adapting; therefore, future important quality-related organizational challenges will lie outside the current QM domain}

The empirically identified challenges support the proposition in terms of pointing to several upcoming challenges that lie outside the current domain of QM. Several of the top 10 challenges (for example, those ranked 2, 5, and 6) point to the need to develop exploratory capabilities within the QM field. To support both capabilities for exploitation and exploration with a variety of QM practices, it may be necessary for an organization to separate those units that need to focus on radical innovations by building on exploratory capabilities from those that focus on incremental innovation; in other words, an organization needs to be ambidextrous (O'Reilly and Tushman, 2008; Raish et al., 2009). To support the evolution of QM into adjacent areas, as suggested by Sousa and Voss (2002), there is a need to join forces with other fields of expertise. QM has a strong tradition and proven benefits in the exploitation of existing capabilities (O'Reilly and Tushman, 2004). The development of new QM capabilities might be supported by the proposed collaboration with researchers outside the $\mathrm{QM}$ field; for example from the innovation management field. Moreover, if QM practice is not limited to the QM profession, we propose studies on the separation of the responsibility for exploratory QM practice from a more exploitation-oriented QM practice. This could also enable an operationalization of QM that would vary depending on needs specific to various contexts (Benner and Tushman, 2003).

However, one result from this study is that contextual factors have no significant effect on challenges that are perceived to be critical. The contextual factors studied included organizational size, public or private ownership, and manufacturing or service industries. On the other hand, one factor that appears to affect how QM challenges are perceived is whether the organization is international. It appears that, in an international environment, more exploratory capabilities are needed and challenges related to change management and to being adaptive become critical. We argue that it might be fruitful to look at the evolution of QM in light of the exploitation-exploration perspective. It is likely that the ways QM needs are to be manifested and operationalized depends on the context, thus requiring different types of quality professionals as well as a variety of excellence models. In sum, we suggest that research is needed on how QM can evolve in different contexts, with a range of needs in terms of adaptive and explorative capabilities.

The customer focus is a basic and non-disputed principle of QM and is one of three in the commonly cited framework of Dean and Bowen (1994). Considering the importance of customers in QM, it is somewhat surprising that challenges related to customers were ranked as 7,8 , and 10 in the top-ranked challenges. On the other hand, it could be considered surprising that customer-related challenges are ranked highly at all, given that customers have been the main focus for QM for decades. A critical aspect underlying this ambiguous view on attention to customers may lie in the details of how the challenges were formulated. The challenges constituting this theme are: "To understand our stakeholders' needs and expectations" (rank 7), "To involve customers in improvement activities" (rank 8), and "To build long-term relationships 
with customers" (rank 10). The first of these challenges, ranked 7, points to a broader view on customers as stakeholders, rather than solely focusing on customers as the buyers or users of an offering. This may indicate the need to expand the view of the customer to encompass all stakeholders, including society and the natural environment, as argued in relation to sustainability by such researchers as Angell and Klassen (1999) and Bergquist et al. (2012); even though a specific challenge concerning sustainability was initially ranked 31 by the respondents. The customer-related challenges ranked as 8 and 10 point to the need for customers to be involved not only by stating their needs and expectations, but also as partners in general, and specifically as partners in improvement work. This high degree of involvement is in line with the view on QM that has been labeled "sustainable competitive quality," in which Lengnick-Hall (1996) argued that customers should be viewed as co-producers of value in loyalty-producing relationships. Many authors have argued for the benefit of finding different ways to include stakeholders, including customers, in value creation so that value can be created in new and better ways (see, for example, an early article by Normann and Ramirez, 1993). In sum, we recommend that research be conducted on the interfaces between QM and sustainability in general, and specifically on how customers and stakeholders can actively contribute towards improvements.

Watkins (2006) argued that quality professionals need to widen their views, be more strategic, and move away from their current narrow role, with responsibilities limited to handling certified QM systems (Elg et al., 2011). The results of the present study partly point to a need for more research on how to increase the focus on QM at a strategic level, and especially on how owners and managers can take more responsibility for quality. The highly ranked challenge of making QM into a strategic issue for company owners is not well covered by any of the examined models in particular or by QM in general. The low coverage is surprising given that the principle of evident ownership is often claimed to be of paramount importance within the QM, and as a means for initiating change. However, it is important to point out the distinction between top management involvement, which has been the focus of $\mathrm{QM}$ literature, and the involvement of the owners. Alänge and Steiber (2009) found that board members in one of the firms they studied thought that quality-related questions should be on the table. In the same study, the CEO of another firm chose not to engage the board in improving operational efficiency, since the members were perceived to lack competence and experience and the CEO thought that quality improvements went beyond the board's more strategic function (ibid.). There is a lack of research on how to engage owners in instigating quality improvement, and the importance of this engagement. Therefore, we believe that research is needed on the role of owners and the board of directors in $Q M$, and how to organize and distribute responsibilities for QM work in general.

\section{Proposition II: The current principles and values of the excellence models do not support organizations when they are faced with future quality-related challenges}

The empirical work shows that the current principles and values of the excellence models, as suggested in the initial proposition, do not cover all top-rated challenges. However, our study indicates that excellence models still seem to be relevant for many organizations as they address many of the stated challenges. It can be argued that even if most of the highly prioritized challenges are covered, no excellence model alone will be sufficient for addressing all of the challenges met by every organization. 
Among the top-ranked challenges, no model was considered to aim, either explicitly or implicitly, to address the need to make quality a strategic concern for the owners - an area that previous research has argued to be critical (Alänge and Steiber, 2009). Moreover, the respondents prioritized customer involvement for making improvements, and the development of processes that are robust, yet still easily adaptable. The involvement of customers in co-creating value is believed to be advantageous in, for example, the development of new market offers (Witell et al., 2011). Co-creation is sometimes inherent in the production, such as in service production areas, so this need extends beyond situations where customers are already deeply involved. However, the challenges focusing on customer involvement and adaptability were found to have low model coverage. The excellence models do not incorporate principles and values that cover certain challenges - making QM a strategic issue for company owners, involving customers in the improvement activities, and developing processes that are robust - while still being easily adaptable. Therefore, we conclude that there is a research need to determine whether excellence models need to be developed so that such needs are met, or if including such needs would have other negative effects that outweigh any benefits of such inclusions such as increased model complexity.

\section{Limitations}

MacCarthy and Atthirawong (2003) concluded that the strength of the Delphi approach is that it provides a greater understanding of complex problems than other survey techniques. Our Delphi study has explored quality-related challenges and, even though its design has helped us understand a complex future, it has certain limitations. Many professionals want managers to attend to their own field of expertise. Therefore, it is possible to speculate that managerial attention to their own specific expertise and interest would be among the top challenges for any professional group. Therefore, there would probably be some bias when surveying professionals that have an interest in and experience of QM. On the other hand, if the survey had been directed only towards top management, many challenges that were considered important by the quality professionals would probably not have surfaced and important challenges would have been missed. Nonetheless, the practitioners see the need for more managerial attention. Moreover, the way that a challenge is phrased - for example, how broad or detailed the challenge is - would probably influence the choice of the respondents. When scrutinizing the challenges, some have a more obvious link to improvements, while others may be seen as organizationally internal challenges that, when solved, could only be considered as a stepping-stone towards improved processes or product quality.

\section{Conclusions}

This study has contrasted two theoretical propositions about $\mathrm{QM}$ and business excellence with the findings from a performed Delphi study on quality related organizational challenges as a means of proposing ideas for future research.

\section{What are the future quality-related organizational challenges?}

The top ten challenges identified were: (1) to transfer the ownership of quality from the quality profession to management; (2) to make the organization agile and adaptable to rapid changes within the business environment; (3) to make quality a strategic concern for the owners; (4) to develop an improvement 
culture within the organization; (5) to lead and accomplish change; (6) to develop processes that are robust yet (7) still easily adaptable; (8) to understand stakeholders' needs and expectations; (9) to involve customers in the improvement activities; and (10) to improve the operational efficiency for increased competitiveness. The three top-ranked challenges stand out regarding importance compared to the other challenges. There were surprisingly few differences in the challenges foreseen by different types of organizations.

\section{Do current excellence models address these challenges?}

The excellence models were established during a time when the challenges facing organizations were different from those they face now. This study indicates that the excellence models still seem to be relevant for many organizations, since the content of the models still matches many of the challenges identified by the respondents to our survey. The MBNQA and the SIQ models were found to include the most comprehensive coverage of the top 10 challenges identified. Many of the challenges received limited coverage in the ISO model principles, even though the ISO model is undoubtedly the most widely applied and, in many contexts, seen as synonymous to QM. The development needs for the excellence models cover the following: "making QM a strategic issue for company owners", "involving customers in the improvement activities" and "developing processes that are robust, yet still easily adaptable." In sum, the empirical work also shows that the current principles and values of the excellence models do not cover the future quality-related organizational challenges. The study reveals the need for further development of excellence models or at least more studies of whether the models would benefit from such broadening of their scope. One particular conclusion is that research should be devoted to studies of whether the excellence models need to be developed so that they incorporate principles and values that cover the following challenges: making QM a strategic issue for company owners; involving customers in the improvement activities; and developing processes that are robust, yet still easily adaptable. It is likely that many of the challenges identified in the current study are common to many Western countries.

\section{What are the implications for future research on business excellence and quality management?}

The present study suggests that QM is still adopting and adapting to the changing business environment and that some important challenges lie outside the current domain of QM. Research is required into three areas: (1) how QM can evolve in different contexts, with a range of needs in terms of adaptive and explorative capabilities, and (2) on the interfaces between QM and sustainability, and to understand how customers and stakeholders can actively contribute towards improvements; and (3) the role of owners and the board of directors in $\mathrm{QM}$ and how to organize and distribute responsibilities for QM work.

\section{References}

Aichholzer, G. (2009), “Chapter 12: The Delphi-method: Eliciting experts' knowledge in technology foresight", in Bogner A., Littig B. and Menz W. (Eds.) Interviewing Experts, Palgrave Macmillan, Basingstoke, pp. 252-274.

Alänge, S. and Steiber, A. (2009), "The board's role in sustaining major organizational change - An empirical analysis of three change programs", International Journal of Quality and Service Sciences, Vol. 1 No. 3, pp. 280-293. 
Angell, L.C. and Klassen, R.D. (1999), "Integrating environmental issues into the mainstream: and agenda for research in operations management", Journal of Operations Management, Vol. 17 No. 5, pp. 575-598.

Asif, M., Searcy, C., Garvare, R. and Ahmad, N. (2011), "Including sustainability in business excellence Models", Total Quality Management \& Business Excellence, Vol. 22 No. 7, pp. 773-786.

Batalden, P. and Davidoff, F. (2007), "What is quality improvement and how can it transform healthcare?", Quality and Safety in Health Care, Vol. 16 No. 1, pp. 2-3.

Benner, M.J. and Tushman, M.L. (2003), "Exploitation, exploration and process management: The productivity dilemma revisited", Academy of Management Review, Vol. 28 No. 2, pp. 238-256.

Benner, M.J. and Veloso, F.M. (2008), "ISO 9000 practices and financial performance: a technology coherence perspective", Journal of Operations Management, Vol. 26 No. 5, pp. 611-629.

Bergquist, B., Garvare, R., Eriksson, H., Hallencreutz, J., Langstrand, J., Vanhatalo, E. and Zobel, T. (2012), "Alive and kicking - but will Quality Management be around tomorrow? A Swedish academia perspective", Quality Innovation Prosperity, Vol. 16 No. 2, pp. 1-18.

Calvo-Mora, A., Picón, A., Ruiz, C. and Cauzo, L. (2014), "The relationship between soft-hard TQM factors and key business results", International Journal of Operations and Production Management, Vol. 34 No. 1, pp. 115-143.

Cândido, C. J.F., Coelho, L. M.S. and Peixinho, R.M.T., (2016),"The financial impact of a withdrawn ISO 9001 certificate", International Journal of Operations \& Production Management, Vol. 36 No. 1, pp. -

Chatzoglou, P., Chatzoudes, D. and Kipraios, N. (2015), "The impact of ISO 9000 certification on firms' financial performance", International Journal of Operations \& Production Management, Vol. 35 No. 1, pp. 145-174.

Curkovic, S., Melnyk, S., Calantone, R., and Handfield, R. (2000), "Validating the Malcolm Baldrige National Quality Award framework through structural equation modelling", International Journal of Production Research, Vol. 38 No. 4, pp. 765-791.

Dahlgaard-Park, S.M. and Dahlgaard, J.J. (2007), "Excellence - 25 years evolution", Journal of Management History, Vol. 13 No. 4, pp. 371-393.

Dalkey, N.C. (1969), The Delphi method: An experimental study of group opinion, Rand Corporation, Santa Monica, CA.

Dean, J.W. and Bowen, D.E. (1994), "Management theory and total quality: Improving research and practice through theory development", The Academy of Management Review, Vol. 19 No. 3, pp. 392-418.

EFQM. (2013), EFQM Excellence Model, European Foundation for Quality Management, Brussels.

Elg, M., Gremyr, I., Hellström, A. and Witell, L. (2011), "The role of quality managers in contemporary organizations", Total Quality Management and Business Excellence, Vol. 22, No. 8, pp. 795-806. 
Eriksson, H. (2003a), "Organizational value of participating in a quality award process. A Swedish study", The TQM Magazine, Vol. 16 No. 2, pp. 78-92.

Eriksson, H. (2003b), "Experiences of working with in-company quality awards - A case study", The TQM Magazine, Vol. 15 No. 2, pp. 397-407.

Eriksson, H. and Garvare, R. (2005), "Organizational performance improvement through quality award process participation", International Journal of Quality and Reliability Management, Vol. 22 No. 9, pp. 894-912.

Eriksson, H. and Hansson, J. (2003), "The impact of TQM on financial performance", Measuring Business Excellence, Vol. 7 No. 1, pp. 36-50.

Fundin, A., Witell, L. and Gebauer, H. (2012), "Service transition: Finding the right position on the goodsto-services continuum", International Journal of Modelling in Operations Management, Vol. 1 No. 1, pp. 69-88.

Flynn, B.B., Schroeder, R.G. and Sakakibara, S. (1994), "A framework for quality management research and an associated measurement instrument", Journal of Operations Management, Vol. 11 No. 4, pp. 339366.

Garvin, D.A. (1988), Managing Quality - The strategic and competitive edge, The Free Press, New York, NY.

Genovich-Richards, J. (1997), "Selecting Quality Initiatives and Methodologies", in Meisenheimer, C.G. (Ed.): Improving Quality: A Guide to Effective Programs, Aspen Publishers, Inc., Gaithersburg.

Ghobadian, A. and Woo, H.S. (1994), "Characteristics, benefits and shortcomings of four major quality awards", International Journal of Quality and Reliability Management, Vol. 13 No. 2, pp. 10-44.

Gremyr, I., Löfberg, N. and Witell, L. (2010), "Service Innovations in Manufacturing Firms", Managing Service Quality, Vol. 20 No. 2, pp. 161-175.

Gremyr, I., Siva, V., Raharjo, H. and Goh, T.N. (2014), "Adapting the Robust Design Methodology to support sustainable product development", Journal of Cleaner Production, in press, DOI: 10.1016/j.jclepro.2014.05.018.

Häder, M. and Häder, S. (2000), "Die Delphi-Technik in den Sozialwissenschaften: 11-31", in Häder, M. and Häder S. (Eds.) Metodishe forshungen und innovative anwendungen. Westdeutcher Verlag, Wiesbaden.

Hendricks, K.B. and Singhal, V.R. (1997), "Does implementing an effective TQM program actually improve operating performance? Empirical evidence from firms that have won quality awards", Management Science, Vol. 43 No. 9, pp. 1258-1274. 
Heras-Saizarbitoria, I. and Boiral, O. (2013), "ISO 9001 and ISO 14001: Towards a Research Agenda on Management System Standards", International Journal of Management Reviews, Vol. 15 No. 1, pp. 47-65. Jayamaha, N., Grigg, N. and Mann, R. (2009), "A study of the validity of three major business excellence models in the Asia Pacific region", Total Quality Management, Vol. 20 No. 11, pp. 1213-1227.

Karimi, A., Safari, H., Hashemi, S.H. and Kalantar, P. (2014), "A study of the Baldrige Award framework using the applicant scoring data", Total Quality Management \& Business Excellence, Vol. 25 No. 5-6, pp. 461-477.

Kawakita, J. (1981), The original KJ method (Revised edition), Kawakita Research Institute, Tokyo.

Kaye, M. and Anderson, R. (1999), "Continuous improvement: the ten essential criteria", International Journal of Quality and Reliability Management, Vol. 16 No. 5, pp. 485-509.

Keeney, S. (2009), "The Delphi technique", in K. Gerrish, A. Lacey (Eds.), The Research Process in Nursing, Blackwell Publishing, London.

Krippendorff, K. (1980), Content analysis: An introduction to its methodology, Sage, Beverly Hills, CA.

Lengnick-Hall, C. (1996), "Customer Contributions to Quality: A Different View of the Customer-Oriented Firm", The Academy of Management Review, Vol. 21 No. 3, pp. 791-824.

Linstone, H.A. and Turoff, M. (1975), The Delphi Method: Techniques and Applications, Addison-Wesley, London.

Lombard, M., Snyder-Duch, J. and Bracken, C.C. (2002), "Content analysis in mass communication: Assessment and reporting of intercoder reliability", Human Communication Research, Vol. 28 No. 4, pp. 587-604.

MacCarthy, B.L. and Atthirawong, W. (2003), "Factors affecting location decisions in international operations - a Delphi study", International Journal of Operations \& Production Management, Vol. 23 No. 7, pp. 794-818.

Martínez-Costa, M., Choi, T.Y., Martínez, J.A. and Martínez-Lorente, A.R. (2009), "ISO 9000/1994, ISO 9001/2000 and TQM: the performance debate revisited", Journal of Operations Management, Vol. 27, pp. 495-511.

NIST. (2014), 2013-2014 Criteria for Performance Excellence. Electronic reference: http://www.nist.gov/baldrige/publications/business nonprofit criteria.cfm. Access date: June 3, 2014.

Normann, R. and Ramirez, R. (1993), "Designing interactive strategy: from value chain to value constellation", Harvard Business Review, Vol. 71, pp. 65-77, July-August.

Näslund, D. (2008), "Lean, six sigma and lean sigma: fads or real process improvement methods?", Business Process Management Journal, Vol. 14, No. 3, pp. 269-287. 
Okoli, C. and Pawlowski, S.D. (2004), "The Delphi method as a research tool: an example, design considerations and applications", Information and Management, Vol. 42 No. 1, pp. 15-29.

O'Reilly, C.A. and Tushman, M.L. (2004), “The Ambidextrous Organization”, Harvard Business Review, Vol. 82 No.4, pp. 74-81.

O'Reilly, C.A. and Tushman, M.L. (2008), “Ambidexterity as a dynamic capability: Resolving the innovator's dilemma”, Research in Organizational Behavior, Vol. 28, pp. 185-206.

Raisch, S., Birkinshaw, J., Probst, G. and Tushman, M.L. (2009), “Organizational Ambidexterity: Balancing Exploitation and Exploration for Sustained Performance", Organization Science, Vol. 20 No. 4, pp. 685695.

Rescher, N. (1998), Predicting the Future: An Introduction to the Theory of Forecasting, State University of New York Press, Albany, NY.

Ritter, M., Sohal, A.S. and D'Netto, B. (1998), "Attributes of an outstanding manufacturing manager", International Journal of Manpower, Vol. 19 No. 3, pp. 145-160.

Sabella, A., Kashou, R. and Omran, O. (2014), "Quality Management Practices and their relationship to organizational performance", International Journal of Operations and Production Management, Vol. 34 No. 12 , pp. 1487-1505.

Shewhart, W.A. (1931), Economic control of quality of manufactured product, Van Nostrand, New York, NY.

Shewhart, W.A. (1939), Statistical method from the viewpoint of quality control, Graduate School of the Department of Agriculture, Washington D.C.

Sila, I. and Ebrahimpour, M. (2003), "Examination and comparison of the critical factors of total quality management (TQM) across countries", International Journal of Production Research, Vol. 41 No. 2, pp. 235-268.

SIQ. (2014), The SIQ model for performance excellence, Swedish Institute for Quality (SIQ), Gothenburg.

Sousa, R. and Voss, C.A. (2002), "Quality management re-visited: a reflective review and agenda for future research", Journal of Operations Management, Vol. 20 No. 1, pp. 91-109.

Stratton, B. (1996), "The future of the quality profession", Quality Progress, Vol. 29 No. 7, pp. 26-27.

Talwar, B. (2011), "Business excellence models and the path ahead ...", The TQM Journal, Vol. 23 No 1, pp. 21-35.

Taylor, F.W. (1911), The principles of scientific management. Harper and Brothers, New York, NY.

Van der Wiele, A., Williams, A.R.T. and Dale, B.G. (2000), "Total quality management. Is it a fad, fashion, or fit?", Quality Management Journal, Vol. 7 No. 2, pp. 65-79. 
van der Wiele, T., van Iwaarden, J., Williams, R. and Eldridge, S. (2011), "A new foundation for quality management in the business environment of the twenty-first century", Total Quality Management \& Business Excellence, Vol. 22 No. 5, pp. 587-598.

Watkins, D. (2006), "Reflections on the Future of Quality", Quality Progress, Vol. 39 No. 1, pp. 23-28.

Wiengarten, F., Pagell, M. and Fynes, B. (2013), "ISO 14000 certification and investments in environmental supply chain management practices: identifying differences in motivation and adoption levels between Western European and North American companies", Journal of Cleaner Production, Vol. 56, October, pp. 18-28.

Williams, R., Bertsch, B., Van der Wiele, A., Van Iwaarden, J. and Dale, B. (2006), "Self-Assessment Against Business Excellence Models: A Critique and Perspective", Total Quality Management and Business Excellence, Vol. 17 No. 10, pp. 1287-1300.

Witell, L., Kristensson, P., Gustafsson, A. and Löfgren, M. (2011), "Idea generation: customer co-creation versus traditional market research techniques", Journal of Service Management, Vol. 22 No. 2, pp. 140159.

Yong, J. and Wilkinson, A. (2002), "The long and winding road: the evolution of quality management", Total Quality Management, Vol. 13 No. 1, pp. 101-121.

Table 1. The core principles and values of the excellence models. Excellence models in Sweden (the SIQ model), in Europe (the EFQM), in the US (the MBNQA), and internationally (the ISO 9001) are presented. The principles are clustered by the authors to show similarities between the models.

\begin{tabular}{|c|c|c|c|c|}
\hline Key themes & MBNQA & EFQM & SIQ & ISO 9001 \\
\hline Leadership & $\begin{array}{l}\text { Visionary } \\
\text { leadership }\end{array}$ & $\begin{array}{l}\text { Leading with vision, } \\
\text { Inspiration, and integrity }\end{array}$ & Committed leadership & Leadership \\
\hline Customers & $\begin{array}{l}\text { Customer-driven } \\
\text { excellence }\end{array}$ & $\begin{array}{l}\text { Adding value for } \\
\text { customers }\end{array}$ & Customer orientation & Customer focus \\
\hline People & $\begin{array}{l}\text { Organizational and } \\
\text { personal learning, } \\
\text { and } \\
\text { valuing workforce } \\
\text { members and } \\
\text { partners }\end{array}$ & $\begin{array}{l}\text { Succeeding through the } \\
\text { talent of people, and } \\
\text { developing } \\
\text { organizational } \\
\text { capability }\end{array}$ & $\begin{array}{l}\text { Competence } \\
\text { development and } \\
\text { participation by } \\
\text { everyone }\end{array}$ & $\begin{array}{l}\text { Involvement of } \\
\text { people }\end{array}$ \\
\hline Processes & & & Process orientation & Process approach \\
\hline $\begin{array}{l}\text { Improve and } \\
\text { Innovate }\end{array}$ & $\begin{array}{l}\text { Managing for } \\
\text { innovation }\end{array}$ & $\begin{array}{l}\text { Harnessing creativity and } \\
\text { innovation }\end{array}$ & \begin{tabular}{|l} 
Continuous \\
improvement and \\
learning from others
\end{tabular} & $\begin{array}{l}\text { Continual } \\
\text { improvement }\end{array}$ \\
\hline Agility & Agility & Managing with agility & $\begin{array}{l}\text { Faster response } \\
\text { (reactions) }\end{array}$ & \\
\hline
\end{tabular}




\begin{tabular}{|l|l|l|l|l|}
\hline $\begin{array}{l}\text { Management by } \\
\text { facts }\end{array}$ & $\begin{array}{l}\text { Management by } \\
\text { facts }\end{array}$ & Management by facts & $\begin{array}{l}\text { Factual approach } \\
\text { to decision } \\
\text { making }\end{array}$ \\
\hline $\begin{array}{l}\text { System approach } \\
\text { and perspective }\end{array}$ & Systems perspective & $\begin{array}{l}\text { System approach } \\
\text { to management }\end{array}$ \\
\hline Results & $\begin{array}{l}\text { Focus on results } \\
\text { and } \\
\text { creating value }\end{array}$ & $\begin{array}{l}\text { Sustaining outstanding } \\
\text { results }\end{array}$ & & Mutually \\
\hline $\begin{array}{l}\text { Relationship with } \\
\text { partners }\end{array}$ & $\begin{array}{l}\text { beneficial supplier } \\
\text { relationship }\end{array}$ \\
\hline Sustainability & $\begin{array}{l}\text { Societal } \\
\text { responsibility }\end{array}$ & $\begin{array}{l}\text { Creating a sustainable } \\
\text { future }\end{array}$ & Public responsibility & \\
\hline Future perspective & Focus on the future & & $\begin{array}{l}\text { Prevention and long- } \\
\text { range perspective }\end{array}$ & \\
\hline
\end{tabular}


Table 2. Challenges ranked by their importance in the final Delphi round (sum of scores). The table also shows in which round each challenge was added.

\begin{tabular}{|c|c|c|c|}
\hline Rank & Challenges & $\begin{array}{l}\text { Sum of } \\
\text { scores }\end{array}$ & $\begin{array}{l}\text { Added in } \\
\text { round }\end{array}$ \\
\hline 1 & To transfer the ownership of quality from the quality profession to management & 22.3 & 1 \\
\hline 2 & $\begin{array}{l}\text { To make the organization agile and adaptable to rapid changes within the } \\
\text { business environment }\end{array}$ & 22.1 & 1 \\
\hline 3 & To make quality a strategic concern for the owners & 22.1 & 1 \\
\hline 4 & To develop an improvement culture within the organization & 14.8 & 2 \\
\hline 5 & To lead and accomplish change & 13.3 & 3 \\
\hline 6 & To develop processes that are robust, yet still easily adaptable & 11.2 & 1 \\
\hline 7 & To understand stakeholders' needs and expectations & 10.4 & 1 \\
\hline 8 & To involve customers in the improvement activities & 10.2 & 1 \\
\hline 9 & To improve the operational efficiency for increased competitiveness & 10.1 & 1 \\
\hline 10 & To build long-term relationships with customers & 10.1 & 1 \\
\hline 11 & To find ways to use the full potential of staff members & 9.9 & 2 \\
\hline 12 & To engage staff in working with improvements & 9.8 & 1 \\
\hline 13 & To handle variations in customers' needs & 9.1 & 1 \\
\hline 14 & To use staff members' potential for generating innovation & 9.0 & 1 \\
\hline 15 & To increase the rate of process orientation & 8.3 & 1 \\
\hline 16 & To retain competent members of staff & 8.2 & 1 \\
\hline 17 & To design more effective management processes & 8.1 & 2 \\
\hline 18 & To recruit the right staff members & 8.1 & 1 \\
\hline 19 & To ascertain that short-term choices are aligned with long-term goals & 8.1 & 2 \\
\hline 20 & To develop our competence toward constantly changing needs & 7.7 & 1 \\
\hline 21 & To shorten the lead time when developing products & 7.6 & 1 \\
\hline 22 & To improve service development processes & 7.5 & 1 \\
\hline 23 & To reduce the organization's costs of poor quality & 7.3 & 2 \\
\hline 24 & To make use of the development of IT to improve the business & 7.3 & 1 \\
\hline 25 & $\begin{array}{l}\text { To identify and use information external to the organization that can have a } \\
\text { large impact on the organization }\end{array}$ & 7.3 & 1 \\
\hline 26 & To develop an organizational innovation ability & 6.9 & 2 \\
\hline 27 & To maintain competence when key personnel leave the organization & 6.8 & 1 \\
\hline 28 & $\begin{array}{l}\text { To coordinate organizational improvement activities in a geographically } \\
\text { dispersed operation }\end{array}$ & 6.4 & 1 \\
\hline 29 & To combine the need for standardization with the need for innovation & 6.2 & 1 \\
\hline 30 & To develop new forms of operations to comply with customers' needs & 6.0 & 1 \\
\hline 31 & To integrate sustainability in how we work & 5.5 & 1 \\
\hline
\end{tabular}




\begin{tabular}{|c|l|l|c|}
\hline 32 & To take on greater societal responsibility & 5.1 & 1 \\
\hline 33 & To manage the decreasing life-cycle lengths of products and services & 4.9 & 1 \\
\hline 34 & To find new and innovative ways to handle operational development & 4.9 & 1 \\
\hline 35 & To create flexible processes that support innovation & 4.3 & 1 \\
\hline 36 & To increase cooperation with suppliers in the supply chain & 3.9 & 2 \\
\hline 37 & To offer combinations of goods and services & 3.8 & 1 \\
\hline 38 & To connect improvements with obtained results & 3.7 & 2 \\
\hline 39 & To apply deliberate risk-taking for long-term success & 3.5 & 1 \\
\hline 40 & To increase the attractiveness of the workplace & 3.5 & 1 \\
\hline 41 & To handle variation in the business' processes & 2.8 & 1 \\
\hline 42 & To have constant access to organizational improvement competence & 2.7 & 2 \\
\hline 43 & To compete with businesses from low-cost countries & 2.6 & 1 \\
\hline 44 & To systematically base decisions on information from databases and staff & & 1 \\
\hline 45 & To prevent poor staff-member health & 2.5 & 1 \\
\hline 46 & To develop 'green’ innovations & 2.3 & 1 \\
\hline 47 & To exploit social media for the benefit of the organization & 1.8 & 1.3 \\
\hline 48 & To make use of the ethnical and cultural diversity of staff members & 3 \\
\hline 49 & To integrate quality dimensions into purchasing processes & & 1 \\
\hline
\end{tabular}


Table 3. The 10 top-ranked challenges and their coverage in the four excellence models analyzed. Challenge coverage is calculated as described in the Data Analysis section. For each challenge, the excellence model with the highest coverage is marked in bold.

\begin{tabular}{|c|c|c|c|c|c|c|}
\hline \multirow[b]{2}{*}{ Top-Ranked Challenges } & \multicolumn{4}{|c|}{ Coverage in Excellence models } & \multirow{2}{*}{$\begin{array}{l}\text { Mean } \\
\text { Values on } \\
\text { Challenge } \\
\text { Coverage }\end{array}$} & \multirow[b]{2}{*}{ Comments } \\
\hline & EFQM & MBNQA & $\begin{array}{l}\text { ISO } \\
9000\end{array}$ & SIQ & & \\
\hline $\begin{array}{l}\text { 1. To transfer the } \\
\text { ownership of quality } \\
\text { from the quality } \\
\text { profession to } \\
\text { management }\end{array}$ & 0.43 & 0.79 & 0.50 & 0.71 & 0.61 & $\begin{array}{l}\text { MBNQA had the highest } \\
\text { coverage }\end{array}$ \\
\hline $\begin{array}{l}\text { 2. To make the } \\
\text { organization agile and } \\
\text { adaptable to rapid } \\
\text { changes within the } \\
\text { business }\end{array}$ & 1.0 & 0.86 & 0.14 & 0.86 & 0.71 & $\begin{array}{l}\text { Overall high coverage, } \\
\text { except ISO 9000, which } \\
\text { had very low coverage }\end{array}$ \\
\hline $\begin{array}{l}\text { To make quality a } \\
\text { strategic concern for the } \\
\text { owners }\end{array}$ & 0 & 0.21 & 0 & 0 & 0.05 & Overall low coverage \\
\hline $\begin{array}{l}\text { 4. To develop an } \\
\text { improvement culture } \\
\text { within the organization }\end{array}$ & 0.86 & 0.71 & 0.79 & 1.0 & 0.84 & $\begin{array}{l}\text { SIQ had full coverage, } \\
\text { high overall coverage }\end{array}$ \\
\hline $\begin{array}{l}\text { 5. To lead and accomplish } \\
\text { change }\end{array}$ & 0.86 & 0.86 & 0.64 & 0.64 & 0.75 & $\begin{array}{l}\text { EFQM and MBNQA had } \\
\text { very high coverage }\end{array}$ \\
\hline $\begin{array}{l}\text { To develop processes } \\
\text { that are robust, yet still } \\
\text { easily adaptable }\end{array}$ & 0.36 & 0.57 & 0.21 & 0.50 & 0.41 & $\begin{array}{l}\text { Overall low-to-medium } \\
\text { coverage }\end{array}$ \\
\hline $\begin{array}{ll}\text { 7. } & \text { To understand our } \\
\text { stakeholders' needs and } \\
\text { expectations }\end{array}$ & 0.93 & 0.86 & 0.79 & 0.93 & 0.88 & $\begin{array}{l}\text { Overall very high } \\
\text { coverage }\end{array}$ \\
\hline $\begin{array}{l}\text { 8. To involve customers in } \\
\text { improvement activities }\end{array}$ & 0.14 & 0.57 & 0.14 & 0.64 & 0.38 & $\begin{array}{l}\text { Overall low-to-medium } \\
\text { coverage }\end{array}$ \\
\hline $\begin{array}{ll}\text { 9. } & \text { To improve the } \\
\text { operational efficiency for } \\
\text { increased } \\
\text { competitiveness } \\
\end{array}$ & 0.64 & 0.29 & 0.57 & 0.64 & 0.54 & $\begin{array}{l}\text { Overall medium } \\
\text { coverage }\end{array}$ \\
\hline $\begin{array}{lr}\text { 10. } \begin{array}{l}\text { To build } \\
\text { relationships } \\
\text { customers }\end{array} & \text { with } \\
\end{array}$ & 0.43 & 0.79 & 0.36 & 0.64 & 0.55 & $\begin{array}{l}\text { MBNQA had the highest } \\
\text { coverage }\end{array}$ \\
\hline $\begin{array}{l}\text { Mean values on model } \\
\text { coverage based on the } 10 \\
\text { top-ranked challenges }\end{array}$ & 0.56 & 0.65 & 0.41 & 0.66 & & $\begin{array}{l}\text { SIQ and MBNQA had the } \\
\text { highest coverage }\end{array}$ \\
\hline
\end{tabular}




\begin{tabular}{|c|c|c|c|}
\hline $\begin{array}{l}\text { Brainstorming } \\
\text {-12 researchers } \\
\text {-65 challenges }\end{array}$ & $\begin{array}{l}\text { Delphi } \\
\text { methodology } \\
\text { (Steps } 1 \text { and 2) } \\
\text {-17 researchers } \\
\text { - Prioritize } 10 \text { most } \\
\text { important } \\
\text { challenges (and } \\
\text { motivate) } \\
\text {-Add new } \\
\text { challenges } \\
\text { - Review of } \\
\text { methodology }\end{array}$ & $\begin{array}{l}\text { Delphi } \\
\text { methodology } \\
\text { (Step 3) } \\
\text {-16 researchers } \\
\text { - Importance } \\
\text { weight to } 10 \text { of } 49 \\
\text { remaining } \\
\text { challenges } \\
\text { - Review of } \\
\text { methodology }\end{array}$ & $\begin{array}{l}\text { Pilot study review } \\
\text {-2 researchers } \\
\text { - Removal of } \\
\text { duplicates } \\
\text {-38 challenges } \\
\text { remaining } \\
\text { - Review of } \\
\text { methodology }\end{array}$ \\
\hline
\end{tabular}

Figure 1. Overview of the pilot study performed before the actual study. 